\title{
Jasmonic Acid and K-Phosphite Enhance Productivity and Technological Quality of Sugarcane Crop
}

\author{
B. R. A. Moreira ${ }^{1}$, R. S. Viana ${ }^{2}$, L. A. M. Lisboa ${ }^{2}$, P. R. M. Lopes ${ }^{2}$, P. A. M. Figueiredo ${ }^{2}$, S. B. Ramos ${ }^{2}$, \\ C. S. B. Bonini ${ }^{2}$, V. D. R. Trindade ${ }^{1}$, M. G. O. Andrade ${ }^{1} \&$ A. May ${ }^{3}$ \\ ${ }^{1}$ Faculty of Engineering of Ilha Solteira, São Paulo State University, São Paulo, Brazil \\ ${ }^{2}$ College of Agricultural and Technological Sciences, São Paulo State University, São Paulo, Brazil \\ ${ }^{3}$ Embrapa Environment, Brazilian Agricultural Research Corporation, São Paulo, Brazil \\ Correspondence: Ronaldo S. Viana, College of Agricultural and Technological Sciences, São Paulo State \\ University, São Paulo, Brazil. Tel: 55-183-821-7476. E-mail: ronaldo.viana@unesp.com
}

Received: May 6, 2019

doi:10.5539/jas.v11n14p254
Accepted: June 29, $2019 \quad$ Online Published: August 31, 2019

URL: https://doi.org/10.5539/jas.v11n14p254

\begin{abstract}
Plant resistance inducers are cost-effective and environmentally pleasing strategies of plant protection to mitigate biotic and abiotic agents threatening food safety and energy security. We, accordingly, present jasmonic acid and k-phosphite as low-cost strategies to enhance productive yield and technological quality of sugarcane crop. Exogenously treatment of the sugarcane variety 'SP81-3250' consisted of carrying out foliar application of jasmonic acid at 1,1.5 and $2 \mathrm{ml} \mathrm{L}^{-1}$ and K-phosphite at 2, 4 and $6 \mathrm{ml} \mathrm{L}^{-1}$ before crop flowering. Interestingly, both systemic phytorregulator and foliar fertilizer at the lowest doses significantly improved contents of total soluble solids and sucrose, as well as productive yield of fermentable sugars. Jasmonic acid could promote growth and development by triggering either non-enzymatic or enzymatic mechanisms in the host self-defense system to support of external stresses, including herbivory by sugarcane-borer. K-phosphite could improve crop performance by not only releasing water-soluble inorganic ions like phosphorus and potash, but also by signaling synthesis of phytoalexins. Purity of cane juice and productivity of stalks sharply decreased, as the doses of the plant-resistance inducers increased. Jasmonic acid and k-phosphite at unbalanced endogenous levels could inhibit physiological ripening and specific enzymatical activity of alkaline invertases and sucrose-phosphate synthase, thereby influencing bioavailability of sucrose. The lower the sucrose content, the poorer the technological quality of sugarcane crop. The conclusion is, therefore, jasmonic acid and K-phosphite at lower doses prove to be effective induced resistance techniques to produce richer feedstock, with potential to produce ethanol fuel and refined sugar in sugar-energy plants.
\end{abstract}

Keywords: host self-defense system, induced resistance technique, jasmonate-methyl, phytohormone, plant-resistance elicitor, Saccharum sp.

\section{Introduction}

Sugarcane crop (Saccharum sp.) is a higher-grass species grown worldwide. It is not only suitable for large-scale production of bioethanol, refined sugar and jaggery, but also for production of hydrolyzed silage and high-quality fodder for ruminant and non-ruminant herbivores. Further economic purposes include cogeneration of heat and bioelectricity from burnt lignocellulose in high temperature and pressure furnace-boiler system. From the point of view of low-carbon agriculture, sugarcane crop is highly effective to mitigate huge emissions of greenhouse gases threatening environment and health, mainly converting $\mathrm{CO}_{2}$ into added-value products by photosynthesis (Leal et al., 2013; Matsuoka et al., 2014; Milanez et al., 2015).

Brazil is the world's largest producer of sugarcane, followed by India and the People's Republic of China. In this continental-scale tropical country, sugarcane fields extend for roughly 10 million hectares. The state of São Paulo is the foundation holding over fifty-percent domestic production of ethanol from cane juice. However, as new croplands emerge mainly due to industrial decentralization, sugarcane mill plants, biorefineries and distilleries extensively move from Southeast to Midwest and Northeast. Biotic and abiotic stresses abundant within those marginal zones make sugar-energy sector planning difficult and expensive (Goldemberg et al., 2014; Defante et al., 2018). Plant-resistance inducers could protect area-growing sugarcane from experiencing adverse 
effects of pathogens and herbivory pests, water stress by drought or flooding, extreme heat, salinity and soil fertility and other factors declining productive yield and technological quality.

Induced resistance techniques are growing in importance in modern agriculture. Natural and synthetic substances such as acibenzolar-S-methyl, silicates, salicylic acid, jasmonic acid and phosphites tested successfully in many food and energy crops. Biochemically, jasmonic acid refers to the systemic phytorregulator synthetized through linoleic acid's metabolic pathway. Its eventual catabolite is jasmonate-methyl. Jasmonic acid plays pivotal role in the host self-defense system by signaling synthesis of antimicrobial secondary metabolites like aldehydes, alkaloids, phenols, terpenoids and flavonoids, PR-proteins like $\beta$-1,3-glucanases and chitinases, and ROS-scavenging enzymes. K-phosphite is the anionic analogue of phosphoric acid. In plant protection, it not only releases water-soluble inorganic ions like phosphorus and potash, but also triggers phytoalexins (Assunção et al., 2012; Nazar et al., 2011; Yazdanpanah et al., 2011; Gomathi et al., 2012; Javaheri et al., 2012; Palma et al., 2013; Falcioni et al., 2014; Vazirimehr et al., 2014; Fahad et al., 2015; Liza et al., 2016).

We, accordingly, present jasmonic acid and K-phosphite as low-cost strategies to enhance productive yield and technological quality of sugarcane crop.

\section{Method}

\subsection{Location and Plant Material}

We performed the cultivation of the sugarcane variety 'SP81-3250' at the Santo Antônio Ubasa farm, located in the municipality of Sertãozinho, São Paulo, Brazil, $21^{\circ} 07^{\prime} 11^{\prime \prime} \mathrm{S}$ and $47^{\circ} 57^{\prime} 32^{\prime \prime} \mathrm{W}$. The soil of the experimental field is eutrophic yellow-red Latosol, loamy texture. The regional climate is Aw, with predominantly dry winters and rainy summers.

\subsection{Experimental Planning}

A randomized block design composed of jasmonic acid at $1,1.5$ and $2 \mathrm{ml} \mathrm{L}^{-1}$ and $\mathrm{K}$-phosphite at 2,4 and $6 \mathrm{ml}$ $\mathrm{L}^{-1}$, with five replications for each dose. Further, sugarcane plants treated with water served as control.

\subsection{Soil Improvement, Crop Planting and Pest Management}

At the beginning of the 2008/09 crop season, we conducted the soil improvement by carrying out application of $2 \mathrm{t} \mathrm{ha}^{-1}$ dolomitic limestone and $0.6 \mathrm{t} \mathrm{ha}^{-1}$ NPK (04-14-08) fertilizer. Two months later, we hand-planted 0.2 m-length buds of sugarcane into standardized experimental plots consisted of five $5 \mathrm{~m}$-length planting furrows spaced at $1.4 \mathrm{~m}$ apart to each other. Chemical control of sugarcane-borer followed the application of imidacloprid at $1.4 \mathrm{~L} \mathrm{ha}^{-1}$ on sugarcane stalks through a $2 \mathrm{~m}$-long, $\mathrm{CO}_{2}$-pressurized backpack sprayer, containing a set of six 110-02 flat spray nozzles spaced at $0.5 \mathrm{~m}$ apart to each other.

\subsection{Foliar Application of Plant-Resistance Inducers}

Exogenously treatment of the host plant material consisted of carrying out foliar application of jasmonic acid and $\mathrm{K}$-phosphite with the $\mathrm{CO}_{2}$-pressurized backpack sprayer working at $40 \mathrm{psi}$ and $300 \mathrm{~L} \mathrm{ha}^{-1}$ spray flow before crop flowering. During foliar application, temperature and air relative humidity were $25.5 \pm 5{ }^{\circ} \mathrm{C}$ and $70.5 \pm 10.5 \%$, respectively.

\subsection{Assessment of Productive Yield and Technological Quality}

Crop harvesting consisted of cutting sugarcane plants in the three central planting furrows of each plot. For the assessment of productive yield and technological quality of the sugarcane variety 'SP81-3280' following spray application of the plant-resistance inducers, a hydraulic press working at $25 \mathrm{MPa}$ crushed $1.5 \mathrm{~m}$-length stalks, repeating three times. We collected and then assessed cane juice samples to total soluble solids, sucrose, purity, fiber, moisture, productive yield of fermentable sugars and productivity of stalks, as the methodologies by Oliveira et al. (2016).

\subsection{Data Analysis}

For the statistical analysis of the data set, Shapiro-Wilk procedure tested normality of gaussian probability density function prior to running analysis of variance in software $\mathrm{R}$ for statistical computing and graphics ( $\mathrm{R}$ Core Team, 2017). The F statistic tested goodness of fit of statistical models describing productive yield and technological quality of sugarcane crop as a function of dose of jasmonic acid and k-phosphite. 


\section{Results}

\subsection{Effect of Jasmonic Acid on Productive Yield and Technological Quality of Sugarcane Crop}

Foliar application of jasmonic acid on the sugarcane variety 'SP81-3250' had a non-linear effect on all the investigated parameters of productive yield and technological quality as proposed in Figure 1. Total soluble solids, sucrose, purity, productive yield of fermentable sugars and productivity of cane stalks significantly declined with spraying this systemic phytorregulator at higher doses, while the reducing sugars and fiber increased.
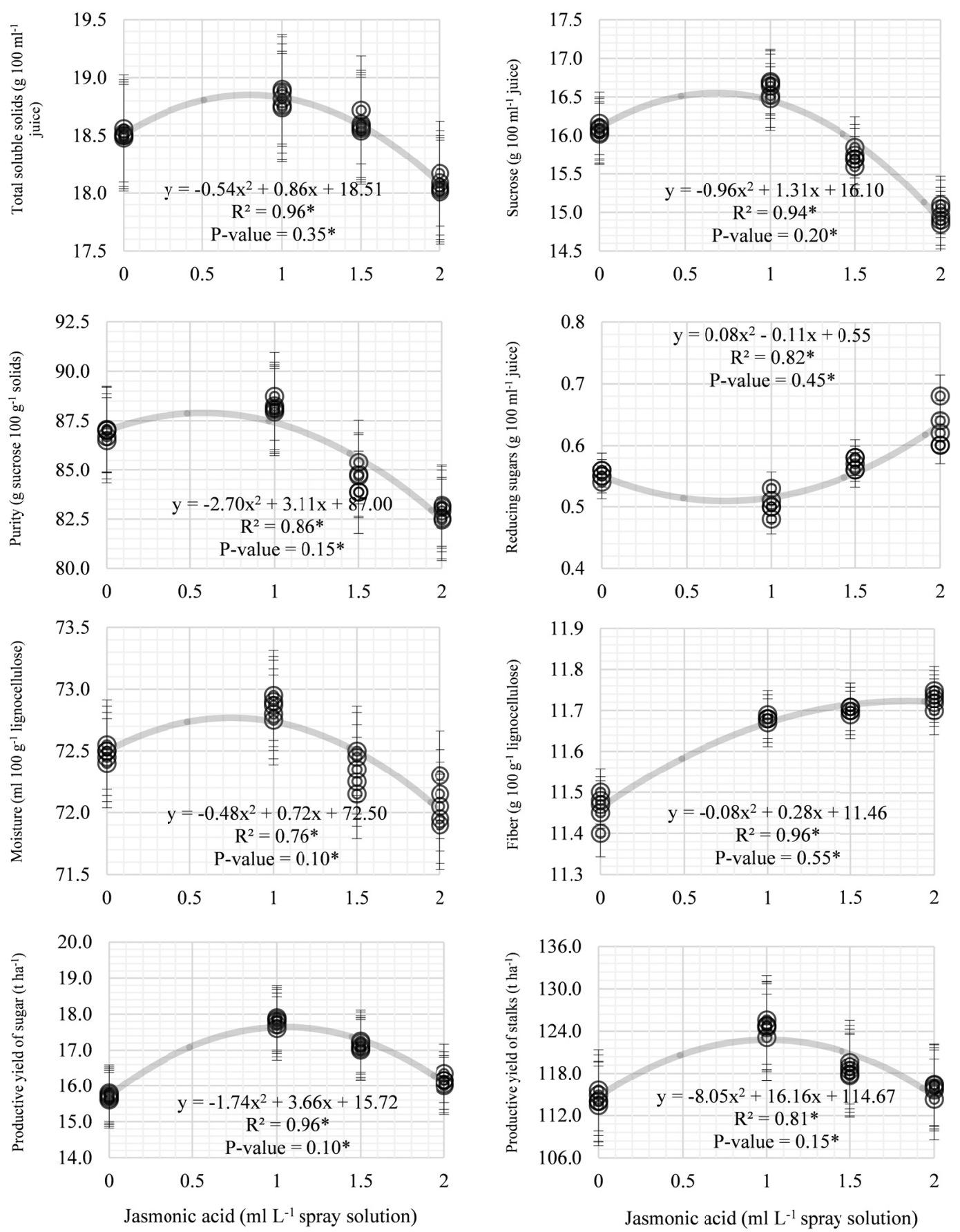

Figure 1. Modeling of effect of jasmonic acid on productive yield and technological quality of the sugarcane variety 'SP81-3250'

Note. * Significant by Shapiro-Wilk and Fisher tests at 0.95 confidence level. 


\subsubsection{Total Soluble Solids}

Samples collected from sugarcane plants treated with jasmonic acid at the lowest dose yielded the highest total soluble solids content, $18.8 \pm 0.05{ }^{\circ}$ Brix. Compared to control, this means a benefit of $0.30 \pm 0.02{ }^{\circ}$ Brix. Increasing dose of jasmonic acid from $1 \mathrm{ml} \mathrm{L}^{-1}$ to $2 \mathrm{ml} \mathrm{L}^{-1}$, decreased total soluble solids content in $0.60 \pm 0.02{ }^{\circ}$ Brix. Therefore, the higher the dose of the systemic phytohormone, the lower the availability of soluble solids in cane juice.

\subsubsection{Sucrose}

Exogenously treatment of sugarcane crop with jasmonic acid at $1 \mathrm{ml} \mathrm{L}^{-1}$ provided the highest sucrose content, $16.6 \pm 0.10 \%$. This plant-resistance inducer at 1.5 and $2 \mathrm{ml} \mathrm{L}^{-1}$ significantly decreased sucrose content from $16.1 \pm 0.10 \%$ to $15.70 \pm 0.10 \%$ and $15 \pm 0.10 \%$ compared to control, respectively. As aforementioned for total soluble solids, sugarcane plants exposed to jasmonic acid at higher doses before crop flowering yielded smaller amounts of sucrose, probably due to hormonally-induced biochemical and physiological stresses.

\subsubsection{Purity}

Sugarcane plants that were only watered produced cane juice samples of $86.9 \pm 0.25 \%$. Foliar application of jasmonic acid at the lowest dose proved to increase degree of purity of cane juice by $1.3 \pm 0.05 \%$. On the contrary, this plant growth regulator tested at $1.5 \mathrm{ml} \mathrm{L}^{-1}$ and $2 \mathrm{ml} \mathrm{L}^{-1}$ led the sugarcane variety 'SP81-3250' to respectively produce $84.5 \pm 0.7 \%$ and $82.5 \pm 0.3 \%$ purity. Hence, doses above than $1 \mathrm{ml} \mathrm{L}^{-1}$ significantly declined purity of cane juice due lower sucrose to soluble solids ratio.

\subsubsection{Reducing Sugars}

Juices samples derived from sugarcane plants developed with jasmonic acid at $1.5 \mathrm{ml} \mathrm{L}^{-1}$ and $2 \mathrm{ml} \mathrm{L}^{-1}$ performed similarly for reducing sugars, with respectively $0.6 \pm 0.05 \%$ and $0.65 \pm 0.05 \%$. Compared to control, both these doses slightly increased reducing sugars content in $0.05 \pm 0.05 \%$ and $0.10 \pm 0.05 \%$, respectively. Because of increased contents of total soluble solids and sucrose, jasmonic acid at $1 \mathrm{ml} \mathrm{L}^{-1}$ forced the sugarcane variety 'SP81-3250' to yield lower cumulative percentage of glucose and fructose.

\subsubsection{Moisture}

Jasmonic acid did not significant effect on water content, as sugarcane plants that were only watered and treated with this phytohormone at $1,1.5$ and $2 \mathrm{ml} \mathrm{L}^{-1}$ produced lignocellulose samples with $72.5 \pm 0.05 \%, 72.85 \pm 0.15 \%$, $72.4 \pm 0.15 \%$ and $72.1 \pm 0.15 \%$, respectively. Indeed, jasmonic acid had no potential to modify degree of hydration of plant tissues.

\subsubsection{Fiber}

From the fitted regression model, jasmonic acid explained almost all the variance within the data of production and accumulation of fiber in the sugarcane variety 'SP81-3250'. Sugarcane plants served as control produced $11.5 \pm 0.4 \%$ fiber, while those that were treated with jasmonic acid at $1,1.5$ and $2 \mathrm{ml} \mathrm{L}^{-1}$, respectively $11.7 \pm 0.01 \%, 11.75 \pm 0.01 \%$ and $11.77 \pm 0.01 \%$. Therefore, the higher the dose of jasmonic acid, the higher the fiber content in lignocellulose portion of sugarcane crop, probably due to lowered sucrose content.

\subsubsection{Productive Yield of Fermentable Sugar}

In sugarcane plants with jasmonic acid at the lowest dose, productive yield of fermentable sugars was $17.8 \pm 0.1 \mathrm{t}$ $\mathrm{ha}^{-1}$. Compared to control, in which productive yield of fermentable sugars was $15.7 \pm 0.1 \mathrm{t} \mathrm{ha}^{-1}, 1 \mathrm{ml} \mathrm{L}^{-1}$ enhanced this parameter in $2.1 \pm 0.01 \mathrm{t} \mathrm{ha}^{-1}$. On the other hand, $1.5 \mathrm{ml} \mathrm{L}^{-1}$ and $2 \mathrm{ml} \mathrm{L}^{-1}$ induced the sugarcane variety 'SP81-3250' to yield $17.1 \pm 0.1 \mathrm{t} \mathrm{ha}^{-1}$ and $16.15 \pm 0.1 \mathrm{t} \mathrm{ha}^{-1}$, respectively. Because of declined sucrose content, jasmonic acid at $2 \mathrm{ml} \mathrm{L}^{-1}$ decreased productive yield of fermentable sugars in $1.65 \pm 0.05 \mathrm{tha}^{-1}$. In fact, jasmonic acid at higher doses was detrimental to crop performance.

\subsubsection{Productivity of Stalks}

The largest productivity of stalks was $124.55 \pm 1.01 \mathrm{t} \mathrm{ha}^{-1}$, when the host plant material developed with jasmonic acid at the lowest dose. Compared to control, in which productivity of stalks was $114.5 \pm 0.9 \mathrm{t} \mathrm{ha}^{-1}, 1 \mathrm{ml} \mathrm{L}^{-1}$ markedly improved this parameter of crop performance in $10 \pm 0.1 \mathrm{t} \mathrm{ha}^{-1}$. In addition, sugarcane plants with jasmonic acid at 1.5 and $2 \mathrm{ml} \mathrm{L}^{-1}$ yielded $118.5 \pm 0.7 \mathrm{t} \mathrm{ha}^{-1}$ and $115.7 \pm 0.8 \mathrm{t} \mathrm{ha}^{-1}$. Spraying jasmonic acid at lower doses rather than higher doses proved to be much more effective to promote plant growth and development probably by making sugarcane crop to be resistant against stress factors, without negatively influencing vital processes such as photosynthesis and water uptake. 


\subsection{Effect of K-phosphite on Productive Yield and Technological Quality of Sugarcane Crop}

Exogenously treatment of K-phosphite on the sugarcane variety 'SP81-3250' had also a non-linear effect on all the investigated parameters of productive yield and technological quality as proposed in Figure 2. In this case, however, contents of reducing sugars and fiber decreased with spraying the foliar fertilizer at higher doses.
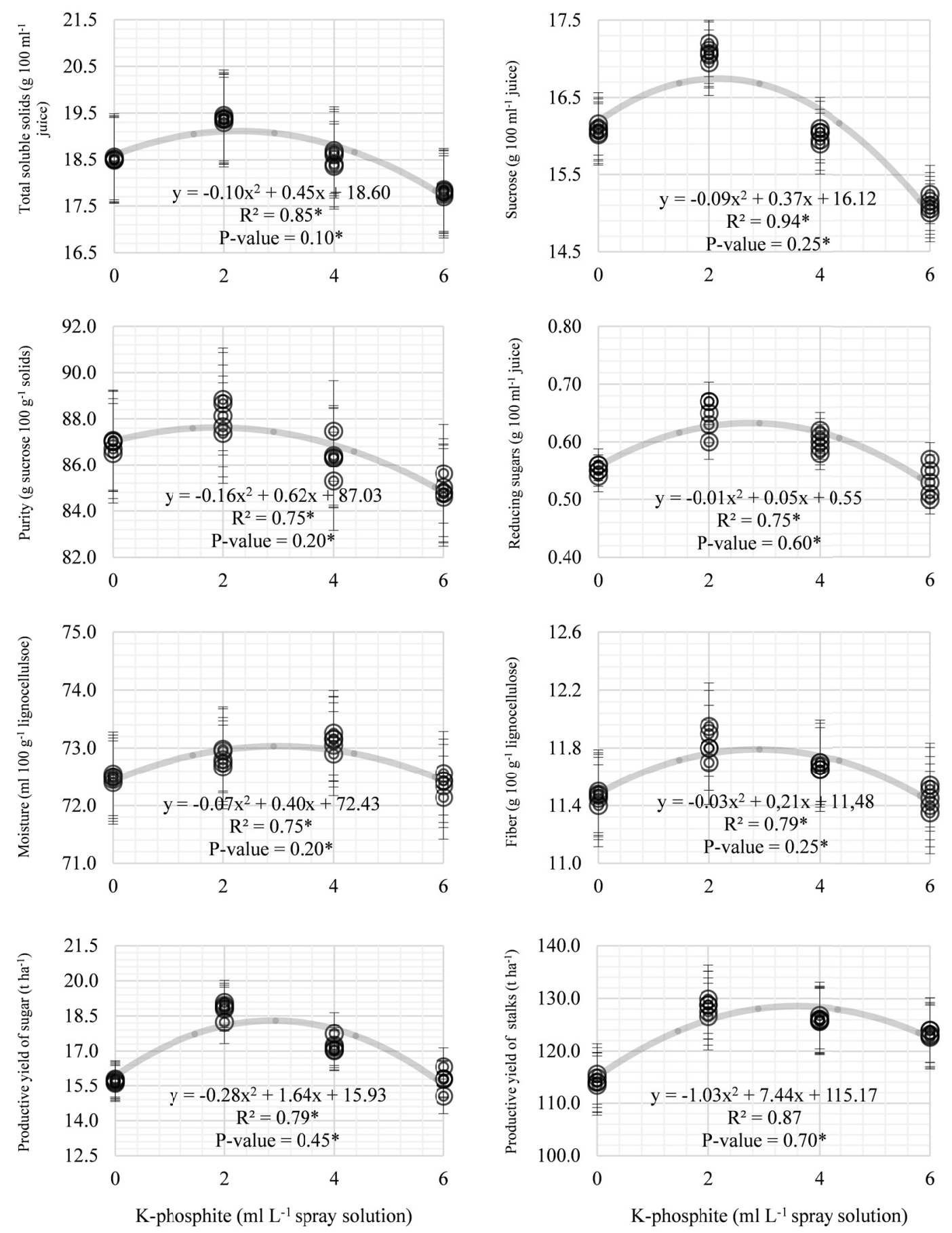

Figure 2. Modeling of effect of K-phosphite on productive yield and technological quality of the sugarcane variety 'SP81-3250'

Note. *Significant by Shapiro-Wilk and Fisher tests at 0.95 confidence level. 


\subsubsection{Total Soluble Solids}

Total soluble solids content in sugarcane plants that were only watered was $18.5 \pm 0.04{ }^{\circ} \mathrm{Brix}$, while the sugarcane plants treated with the foliar fertilizer at the lowest dose yielded the highest content, $19.4 \pm 0.05^{\circ}$ Brix. Therefore, exogenously treatment at $2 \mathrm{ml} \mathrm{L}^{-1}$ increased this parameter of technological quality of cane juice in $0.9 \pm 0.01^{\circ}$ Brix, probably due to releasing of water-soluble inorganic ions. Increasing dose of K-phosphite from 2 $\mathrm{ml} \mathrm{L}^{-1}$ to $4 \mathrm{ml} \mathrm{L}^{-1}$ and $6 \mathrm{ml} \mathrm{L}^{-1}$ declined total soluble solids content in $0.8 \pm 0.05{ }^{\circ}$ Brix and $1.6 \pm 0.01{ }^{\circ}$ Brix, respectively. Therefore, foliar fertilizer sprayed at doses above than $2 \mathrm{ml} \mathrm{L}^{-1}$ was detrimental to production of accumulation of soluble solids in cane juice samples.

\subsubsection{Sucrose}

Cane juice samples collected from sugarcane plants treated with K-phosphite ate the lowest dose yielded the highest sucrose content, $17.1 \pm 0.1 \%$. Compared to control, exogenously application of the foliar fertilizer at $2 \mathrm{ml}$ $\mathrm{L}^{-1}$ significantly increased this parameter in $1.1 \pm 0.05 \%$. On the other hand, $4 \mathrm{ml} \mathrm{L}^{-1}$ and $6 \mathrm{ml} \mathrm{L}^{-1}$ led the sugarcane variety 'SP81-3250' to produce lower sucrose contents, respectively $16 \pm 0.1 \%$ and $15.1 \pm 0.1 \%$. The higher the dose of K-phosphite, the lower the sucrose content, probably due to minerally-induced phytotoxicity.

\subsubsection{Purity}

Purity in sugarcane plants with K-phosphite at the lowest dose was the highest, $88.15 \pm 0.95 \%$, due to increased sucrose to soluble solids ratio. Compared to control, in which purity was $86.9 \pm 0.25 \%$, treatment of foliar fertilizer at $2 \mathrm{ml} \mathrm{L}^{-1}$ increased this parameter in $1.25 \pm 0.4 \%$. The purer the cane juice, the higher the technological quality of biofuel feedstock. Increasing dose of K-phosphite from 2 to 4 and $6 \mathrm{ml} \mathrm{L}^{-1}$, decreased degree of purity in $1.75 \pm 0.55 \%$ and $3.2 \pm 0.55 \%$, respectively, probably due to greater availability of minerals in cane juice samples.

\subsubsection{Reducing Sugars}

In sugarcane plants in absence of the foliar fertilizer, reducing sugars content was $0.55 \pm 0.05 \%$. Compared to control, K-phosphite at $2 \mathrm{ml} \mathrm{L}^{-1}$ increased reducing sugars contents in $0.1 \pm 0.05 \%$. This result was inconsistent with the increased sucrose content. Sucrose is expected to negatively correlates with glucose and fructose.

\subsubsection{Moisture}

Sugarcane plants with K-phosphite at 2, 4 and $6 \mathrm{ml} \mathrm{L}^{-1}$ performed similarly for water content, with $72.8 \pm 0.15 \%$, $73.1 \pm 0.15 \%$ and $72.4 \pm 0.1 \%$, respectively. Compared to control, in which water content was $72.50 \%$, the foliar fertilizer did not significant influence degree of hydration of sugarcane stalks, regardless dose.

\subsubsection{Fiber}

The foliar fertilizer tested at 2, 4 and $6 \mathrm{ml} \mathrm{L}^{-1}$ led the sugarcane variety 'SP81-3250' to respectively produce $11.8 \pm 0.15 \%, 11.5 \pm 0.15 \%$ and $11.45 \pm 0.1 \%$ fiber. Sugarcane plants served as control yielded $11.5 \pm 0.05 \%$ fiber. Therefore, dose of K-phosphite did not significant influence physicochemical composition of lignocellulose portion.

\subsubsection{Productive Yield of Fermentable Sugars}

The largest productive yield of fermentable sugars was $18.8 \pm 0.45 \mathrm{t} \mathrm{ha}^{-1}$ in sugarcane plants with K-phosphite at the lowest dose. Compared to control, in which productive yield of fermentable sugars was $15.7 \pm 0.4 \mathrm{t} \mathrm{ha}^{-1}$, exogenously application of the foliar fertilizer at $2 \mathrm{ml} \mathrm{L}^{-1}$ sharply enhanced this parameter in $3.1 \pm 0.05 \mathrm{t} \mathrm{ha}^{-1}$. Increasing dose of K-phosphite from $2 \mathrm{ml} \mathrm{L}^{-1}$ to $4 \mathrm{ml} \mathrm{L}^{-1}$ and $6 \mathrm{ml} \mathrm{L}^{-1}$, declined productive yield of fermentable sugars in $1.55 \pm 0.15 \mathrm{tha}^{-1}$ and $3.05 \pm 0.05 \mathrm{t} \mathrm{ha}^{-1}$, respectively. The higher the dose of the foliar fertilizer, the lower the production of apparently sucrose.

\subsubsection{Productivity of Stalks}

Productivity of stalks of the sugarcane variety 'SP81-3152' in absence of K-phosphite was $114.4 \pm 0.15 \mathrm{t} \mathrm{ha}^{-1}$. Sugarcane plants treated with the foliar fertilizer had the largest productivity of stalks, $128.50 \pm 0.15 \mathrm{t} \mathrm{ha}^{-1}$. This was a substantial benefit of $14.1 \pm 0.35 \mathrm{tha}^{-1}$, surely due to enhanced plant growth and development as a function of fertilization action of K-phosphite. As aforementioned for productive yield of fermentable sugars, increasing dose of the foliar fertilizer from $2 \mathrm{ml} \mathrm{L}^{-1}$ to $4 \mathrm{ml} \mathrm{L}^{-1}$ and $6 \mathrm{ml} \mathrm{L}^{-1}$, decreased productivity of stalks in $2.4 \pm 0.8 \mathrm{t}$ $\mathrm{ha}^{-1}$ and $5.1 \pm 0.65 \mathrm{tha}^{-1}$, respectively. Whether dose of K-phosphite is higher than $2 \mathrm{ml} \mathrm{L}^{-1}$, crop performance of sugarcane is lower probably due to chemically-induced phytotoxicity. 


\section{Discussion}

\subsection{Total Soluble Solids}

Total soluble solids mostly consist of sucrose, reducing sugars and mineral elements. Jasmonic acid at the lowest dose probably enhanced this parameter by hormonally triggering antimicrobial secondary metabolites and antioxidant enzymes in the host self-defense system, helping the sugarcane variety 'SP81-3250' to deal with eventual stress factors suppressing photosynthesis, physiological ripening and mineral uptake. K-phosphite probably improved availability of soluble solids in cane juice samples collected from sugarcane plants with this foliar fertilizer at lower doses by not only releasing water-soluble inorganic ions like phosphorus and potash, but also by signaling synthesis of phytoalexins. Biochemically, phytoalexins refers to low molecular density antimicrobial secondary metabolites protecting crop plants from pathogens and herbivory pests, including sugarcane-borer. Enhanced plant growth and development as a function of either suppressed pest attack or balanced plant nutrition could had increased availability of total soluble solids and ultimately technological quality of sugarcane crop.

According to Kazemi et al. (2014), who performed the scientific study on the foliar application of salicylic acid and jasmonate-methyl on tomato crop, jasmonate-methyl had also a non-linear effect on total soluble solids content and productivity of fruits, consistent with this work. The scientific study by Ziosi et al. (2008) on the jasmonate-induced transcriptional changes in peach fruits stated overdose of jasmonic acid can drastically reduce total soluble solid content by negatively influencing physiological ripening. Therefore, foliar application of jasmonic acid at 1.5 and $2 \mathrm{ml} \mathrm{L}^{-1}$ on the sugarcane variety 'SP81-3250' could had compromised its physiological ripening due to hormonally-induced oxidative stress by unbalanced ethylene to jasmonic acid ratio. Lowered total soluble solids content in sugarcane plant with K-phosphite at higher doses was probably due to phytotoxicity. The scientific study by Viana et al. (2017) on the productivity and technological quality of sugarcane crop following chemical ripening agents spraying described plant nutrition and physiological ripening as two of the most relevant factors influencing total soluble solids content in cane juice.

Sugarcane mechanical harvesting at 15.5 to $16.50{ }^{\circ}$ Brix guarantees suitable amount of sucrose to sustainably produce refined sugar and first-generation ethanol (Viana et al., 2016). Other authors reported, however, $18.50{ }^{\circ} \mathrm{Brix}$ as optimal content of total soluble solids to enhance alcoholic fermentation by engineered yeasts (Viana et al., 2017). The sugarcane variety 'SP81-3250' treated with jasmonic acid and K-phosphite at the lowest doses produced cane juice with total soluble solids content above than those referenced critical limits.

\subsection{Sucrose}

In saccharine crop plants, sucrose is mainly synthetized by enzymes like sucrose-phosphate synthase and sucrose synthase. Biological fixation of $\mathrm{CO}_{2}$ from the atmosphere and inhibition of auxins are other physiological processes influencing production of sucrose in sugarcane crop (Rivas-San Vicente \& Plasencia, 2011; Monzón et al., 2012). Therefore, both jasmonic acid and K-phosphite at the lowest doses could had increased sucrose content in sugarcane plants by either triggering specific enzymatical activity of sucrose-phosphate synthetase and sucrose synthase or by alleviating external stresses influencing capture of $\mathrm{CO}_{2}$. Improved photoassimilate partitioning due to chemically-suppressed hormonal activity of auxins regulating plant growth and development was another hypothesis. On the contrary, these plant-resistance inducers at higher doses could had decreased sucrose content in cane juice samples probably inducing oxidative stress and acid invertases. Unlike alkaline invertases, acid invertases refer to hydrolytic enzymes converting sucrose into fructose and glucose. Further scientific studies must be performed in order to prove or refute these theories.

From the point of view of sugar-energy sector, sucrose is the most reliable parameter to accurately estimate availability of fermentable sugars in cane juice. This organic substrate is necessary to feed alcoholic fermentation in the making refined sugar and bioethanol (Oliveira et al., 2016). Sugarcane crop is only viable to produce sugar and first-generation ethanol on a commercial scale, if it consists of $14.4 \%$ sucrose (Viana et al., 2017). Based on this literary reference, the sugarcane variety 'SP81-3250' treated with jasmonic acid and $\mathrm{K}$-phosphite at the lowest doses could supply the sugar-energy plants with sucrose-richer feedstock. Indeed, these plant-resistance elicitors proved to be low-cost techniques of plant protection to efficiently enhance technological quality of sugarcane crop.

\subsection{Purity}

Purity surely is essential to generate high quality products of sugarcane in renewable energy production processes. Apart from sucrose to soluble solids ratio, soil colloids, heavy metals, nutrients and monosaccharides can also influence degree of purity of cane juice (Oliveira et al., 2016; Viana et al., 2016). Decreased purity in 
sugarcane plants with jasmonic acid and K-phosphite at higher doses probably was due to endogenous actions of these plant-resistance inducers on specific activity of sucrose-hydrolyzing enzymes, then increasing cumulative percentage of sucrose and fructose. Another hypothesis was greater availability of phosphorus and potash, significantly lowering sucrose to soluble solids ratio.

In production of sugar and bioethanol, cane juice with $75 \%$ purity is industrially pleasing (Oliveira et al., 2016). Degree of purity of the sugarcane variety 'SP81-3250' treated with jasmonic acid and K-phosphite at the lowest dosages was about $13.2 \pm 0.3 \%$ above than requirement of sugar-energy sector. Hence, both these plant-resistance inducers could help sugar-energy sector to produce higher quality products to supply sugar and biofuel markets, as well as food industry.

\subsection{Reducing Sugars}

Jasmonic acid and K-phosphite had different effects on reducing sugars content. Therefore, synthesis of glucose and fructose in the sugarcane variety 'SP81-3250' following alternative treatment with the systemic phytorregulator and foliar fertilizer was dependent on both dose and class of plant-resistance inducer. As aforementioned, jasmonic acid at higher doses could had decreased reducing sugars content in cane juice samples by inhibiting physiological and biochemical processes of synthesis of sucrose, then unbalancing polysaccharide to monosaccharide ratio.

Glucose and fructose play key role in the making refined sugar and bioethanol (Simões et al., 2015). From of perspective of Oliveira et al. (2016), who performed the scientific study on the effect of irrigation on technological quality of sugarcane crop, the higher the cumulative percentage of monosaccharides, the more expensive the refining cost of sugar and the lower the productive yield and quality of ethanol fuel. Both engineered and wild yeasts cannot perform well in alcoholic fermentation of monosaccharide-richer must due to smaller availability of sucrose. Those authors cited $0.8 \%$ reducing sugars as critical limit for industrial procedures by the sugar-energy plant. Despite the increased reducing sugars content, jasmonic acid at the highest dose was not detrimental to technological quality of the sugarcane variety 'SP81-3250'.

\subsection{Moisture and Fiber}

Increased fiber content in sugarcane plants with jasmonic acid at higher dose probably was due to response of the host self-defense to induced oxidative stress. The scientific studies by Jin et al. (2008) and Oliveira et al. (2016) reported plant-resistance elicitors can promote synthesis of secondary metabolites such as lignin, making crop plants to be mechanically resistant against stress factors such as pathogens, herbivory pests, and weather agents causing plant lodging. Stressed crop plants commonly present higher contents of fiber and reducing sugars, but lower contents of sucrose and water, consistent with this work.

Highly fiber content feedstock makes industrial recovery of sucrose difficult and expensive. The scientific studies by Simões et al. (2015) and Oliveira et al. (2016) reported from 11 to $13 \%$ as optimal range of fiber content in sugarcane to feed production of biofuels and refined sugar, as well as cogeneration of heat and bioelectricity from burnt lignocellulose in high temperature and pressure furnace-boiler system. Regardless exogenously treatment of plant-resistance inducers, fiber content in lignocellulose samples of the sugarcane variety 'SP81-3250' agrees with the literary references. Indeed, jasmonic acid and K-phosphite proved to be simple, wise and reliable induced-resistance techniques to enhance production of fermentable sugars, while preserving as much as possible physicochemical quality of lignocellulose portion of sugarcane crop.

\subsection{Productive yield of Fermentable Sugars and Productivity of Stalks}

Declined productive yield of fermentable sugars and productivity of stalks in sugarcane plants treated with jasmonic acid and K-phosphite at higher doses probably were due to adverse effects of these plant-resistance inducers on synthesis of carotenoids, chlorophylls and ethylene, compromising photosynthesis and physiological ripening. In addition, overdoses of jasmonic acid and K-phosphite could had negative effects on biological fixation of $\mathrm{CO}_{2}$, which is the most relevant gaseous substrate for plant growth and development (Del Amor \& Cuadra-Crespo, 2011; Janda et al., 2012; Monzón et al., 2012; Wu et al., 2012; Khan et al., 2013; Falcioni et al., 2014; Liu et al., 2014; Vazirimehr et al., 2014; Teixeira et al., 2015; Liu et al., 2016).

Guimarães et al. (2010), who conducted the scientific study on the effects of plant resistance on the parasitism of Meloidogyne incognita in sugarcane crop, stated both jasmonate-methyl and K-silicate at lower doses significantly suppressed attack of the nematode by enhancing specific enzymatical activity of glucanases and peroxidases. Therefore, jasmonic acid and K-phosphite at lower doses could had improved productive yield of fermentable sugars and productivity of stalks by protecting root system of the sugarcane variety 'SP81-3250' from experiencing negative effects of pathogens and pests living in sugarcane rhizosphere. Linares et al. (2010), 
who performed the scientific study on Botryosphaeria rhodina-produced jasmonate, reported jasmonic acid sprinkled at higher dose prove to be effective to increase dry matter in hot pepper and goldenberry fruits. Hormonal effect of jasmonic acid in both food and energy crops is dependent on dose and plant species.

\section{Conclusion}

The conclusion is, therefore, jasmonic acid and K-phosphite at lower doses prove to be simpler, wiser and reliable induced-resistance techniques to produce higher technological quality feedstock, with potential to feed production of ethanol fuel and refined sugar in sugar-energy plant.

\section{References}

Assunção, A., Santos, L. D. C., Rocha, M. D., Reis, A. D. S., Teixeira, R. A., \& Lima, F. D. O. (2010). Efeito de indutores de resistência sobre Meloidogyne incognita em cana-de-açúcar (Saccharum spp.). Nematologia Brasileira, 34(1), 56-62.

Defante, L. R., Vilpoux, O. F., \& Sauer, L. (2018). Rapid expansion of sugarcane crop for biofuels and influence on food production in the first producing region of Brazil. Food Policy, 79, 121-131. https://doi.org/ 10.1016/j.foodpol.2018.06.005

Del Amor, F. M., \& Cuadra-Crespo, P. (2011). Alleviation of salinity stress in broccoli using foliar urea or methyl-jasmonate: analysis of growth, gas exchange, and isotope composition. Plant Growth Regulation, 63(1), 55-62. https://doi.org/10.1007/s10725-010-9511-8

Fahad, S., Hussain, S., Matloob, A., Khan, F. A., Khaliq, A., Saud, S., \& Faiq, M. (2015). Phytohormones and plant responses to salinity stress: A review. Plant Growth Regulation, 75(2), 391-404. https://doi.org/ 10.1007/s10725-014-0013-y

Falcioni, T., Ferrio, J. P., Del Cueto, A. I., Giné, J., Achón, M. Á., \& Medina, V. (2014). Effect of salicylic acid treatment on tomato plant physiology and tolerance to potato virus X infection. European Journal of Plant Pathology, 138(2), 331-345. https://doi.org/10.1007/s10658-013-0333-1

Goldemberg, J., Mello, F. F., Cerri, C. E., Davies, C. A., \& Cerri, C. C. (2014). Meeting the global demand for biofuels in 2021 through sustainable land use change policy. Energy Policy, 69, 14-18. https://doi.org/ 10.1016/j.enpol.2014.02.008

Gomathi, R., Manobari, G., \& Rakkiyappan, P. (2012). Antioxidant enzymes on cell membrane integrity of sugarcane varieties differing in flooding tolerance. Sugar Tech, 14(3), 261-265. https://doi.org/10.1007/ s12355-012-0156-y

Guimarães, L. M. P., Pedrosa, E. M. R., Coelho, R. S. B., Couto, E. F., Maranhão, S. R. V. L., \& Chaves, A. (2010). Eficiência e atividade enzimática elicitada por metil jasmonato e silicato de potássio em cana-de-açúcar parasitada por Meloidogyne incognita. Summa Phytopathologica, 36(1), 11-15. https://doi.org/10.1590/S0100-54052010000100001

Janda, K., Hideg, É., Szalai, G., Kovács, L., \& Janda, T. (2012). Salicylic acid may indirectly influence the photosynthetic electron transport. Journal of Plant Physiology, 169(10), 971-978. https://doi.org/10.1016/ j.jplph.2012.02.020

Javaheri, M., Dadkhah, A. R., \& Tavallaie, F. Z. (2012). Effects of salicylic acid on yield and quality characters of tomato fruit (Lycopersicum esculentum Mill.). International Journal of Agriculture and Crop Sciences, 4(16), 1184-1187.

Jin, J. B., Jin, Y. H., Lee, J., Miura, K., Yoo, C. Y., Kim, W. Y., \& Yun, D. J. (2008). The SUMO E3 ligase, AtSIZ1, regulates flowering by controlling a salicylic acid-mediated floral promotion pathway and through effects on FLC chromatin structure. The Plant Journal, 53(3), 530-540. https://doi.org/10.1111/ j.1365-313X.2007.03359.x

Kazemi, M. (2014). Effect of foliar application with salicylic acid and methyl jasmonate on growth, flowering, yield and fruit quality of tomato. Bulletin of Environmental, Pharmacology and Life Sciences, 3(2), 154-158.

Khan, M. I. R., Iqbal, N., Masood, A., Per, T. S., \& Khan, N. A. (2013). Salicylic acid alleviates adverse effects of heat stress on photosynthesis through changes in proline production and ethylene formation. Plant Signaling \& Behavior, 8(11), 26374. https://doi.org/10.4161/psb.26374

Leal, M. R. L. V., Walter, A. S., \& Seabra, J. E. A. (2013). Sugarcane as an energy source. Biomass Conversion and Biorefinery, 3(1), 17-26. https://doi.org/10.1007/s13399-012-0055-1 
Linares, A. M., Hernandes, C., França, S. D. C., \& Lourenço, M. V. (2010). Atividade fitorreguladora de jasmonatos produzidos por Botryosphaeria rhodina. Horticultura Brasileira, 28(4), 430-434. https://doi.org/ $10.1590 / \mathrm{S} 0102-05362010000400009$

Liu, P., Li, B., Lin, M., Chen, G., Ding, X., Weng, Q., \& Chen, Q. (2016). Phosphite-induced reactive oxygen species production and ethylene and ABA biosynthesis, mediate the control of Phytophthora capsici in pepper (Capsicum annuum). Functional Plant Biology, 43(6), 563-574. https://doi.org/10.1071/FP16006

Liu, S., Dong Y., Xu, L., \& Kong, J. (2014). Effects of foliar applications of nitric oxide and salicylic acid on salt-induced changes in photosynthesis and antioxidative metabolism of cotton seedlings. Plant Growth Regulation, 73(1), 67-78. https://doi.org/10.1007/s10725-013-9868-6

Liza, S. C., Sáenz, H. H., \& Torres, O. C. (2016). Environmental Effect and Acetylsalicilyc Acid on Agronomic Performance of Three Sweet Potato Genotypes. Open Access Library Journal, 3(10), 1-7. https://doi.org/ 10.4236/oalib.1103009

Matsuoka, S., Kennedy, A. J., Santos, E. G. D. D., Tomazela, A. L., \& Rubio, L. C. S. (2014). Energy cane: Its concept, development, characteristics, and prospects. Advances in Botany, 1-13. https://doi.org/10.1155/ 2014/597275

Milanez, A. Y., Nyko D., Valente, M. S., Sousa, L. C., Bonomi, A. M. F. L. J., Jesus, C. D. F. D., \& Junqueira, T. L. (2015). De promessa à realidade: como o etanol celulósico pode revolucionar a indústria da cana-de-açúcar: Uma avaliação do potencial competitivo e sugestões de política pública. BNDES Setorial, 2015(41), 237-294.

Monzón, G. C., Pinedo, M., Lamattina, L., \& Canal, L. (2012). Sunflower root growth regulation: The role of jasmonic acid and its relationship with auxins. Plant Growth Regulation, 66(2), 129-136. https://doi.org/ 10.1007/s10725-011-9636-4

Nazar, R., Iqbal, N., Syeed, S., \& Khan, N. A. (2011). Salicylic acid alleviates decreases in photosynthesis under salt stress by enhancing nitrogen and sulfur assimilation and antioxidant metabolism differentially in two mungbean cultivars. Journal of Plant Physiology, 168(8), 807-815. https://doi.org/10.1016/j.jplph.2010. 11.001

Oliveira, A. R., Braga, M. B., Simões, W. L., \& Walker, A. M. (2016). Influência de lâminas de irrigação nas características tecnológicas de cana-de-açúcar (pp. 4-20). Embrapa Semiárido-Boletim de Pesquisa e Desenvolvimento (INFOTECA-E).

Palma, F., López-Gómez, M., Tejera, N. A., \& Lluch, C. (2013). Salicylic acid improves the salinity tolerance of Medicago sativa in symbiosis with Sinorhizobium meliloti by preventing nitrogen fixation inhibition. Plant Science, 208, 75-82. https://doi.org/10.1016/j.plantsci.2013.03.015

R Core Team. (2018). R: A Language and Environment for Statistical Computing. R Foundation for Statistical Computing, Vienna, Austria.

Rivas-San Vicente, M., \& Plasencia, J. (2011). Salicylic acid beyond defence: Its role in plant growth and development. Journal of Experimental Botany, 62(10), 3321-3338. https://doi.org/10.1093/jxb/err031

Simões, W. L., Calgaro, M, Coelho, D. S., Souza, M. A., \& Lima, J. A. (2015). Respostas de variáveis fisiológicas e tecnológicas da cana-de-açúcar a diferentes sistemas de irrigação. Revista Ciência Agronômica, 46(1), 11-20. https://doi.org/10.1590/S1806-66902015000100002

Teixeira, E. B., Bolonhezi, A. C., Fernandes, F. M., Ribeiro, N. A., \& Queiroz, C. J. (2015). Características tecnológicas do caldo de variedades de cana-de-açúcar cultivadas em solo de cerrado com diferentes níveis de adubação fosfatada. Científica, 44(1), 23-34. https://doi.org/10.15361/1984-5529.2016v44n1p23-34

Vazirimehr, M., Rigi, K., \& Branch Z. (2014). Effect of salicylic acid in agriculture. International Journal of Plant, Animal and Environmental Science, 4, 291-296.

Viana, R. S., Figueiredo, P. A. M., Lisboa, L. A. M., Assumpção, A. C. N. D., Sá, M. E., \& May, A. (2016). Aplicação de fitorreguladores químicos na qualidade tecnológica do sorgo sacarino cv. Biomatrix 535. Revista Brasileira de Milho e Sorgo, 14(3), 326-334. https://doi.org/10.18512/1980-6477/rbms.v14n3 p326-334

Viana, R. S., Lisboa, L. A. M., Figueiredo, P. A. M., \& Neto, A. D. R. (2017). Parâmetros tecnológicos e produtivos da cana-de-açúcar quando submetida à aplicação de maturadores químicos no início de safra. Revista Brasileira de Herbicidas, 16(1), 67-75. https://doi.org/10.7824/rbh.v16i1.496 
Wu, H., Wu, X., Li, Z., Duan, L., \& Zhang, M. (2012). Physiological evaluation of drought stress tolerance and recovery in cauliflower (Brassica oleracea L.) seedlings treated with methyl jasmonate and coronatine. Journal of Plant Growth Regulation, 31(1), 113-123. https://doi.org/10.1007/s00344-011-9224-X

Yazdanpanah, S., Baghizadeh, A., \& Abbassi, F. (2011). The interaction between drought stress and salicylic and ascorbic acids on some biochemical characteristics of Satureja hortensis. African Journal of Agricultural Research, 6(4), 798-807.

Ziosi, V., Bonghi, C., Bregoli, A. M., Trainotti, L., Biondi, S., Sutthiwal, S., \& Torrigiani, P. (2008). Jasmonate-induced transcriptional changes suggest a negative interference with the ripening syndrome in peach fruit. Journal of Experimental Botany, 59(3), 563-573. https://doi.org/10.1093/jxb/erm331

\section{Copyrights}

Copyright for this article is retained by the author(s), with first publication rights granted to the journal.

This is an open-access article distributed under the terms and conditions of the Creative Commons Attribution license (http://creativecommons.org/licenses/by/4.0/). 